\title{
An Alternative Dynamic SBM Measure: A Case of the information Technology Sector in Turkey
}

\author{
Ümran Şengül $1^{1} \&$ Miraç Eren ${ }^{2}$ \\ ${ }^{1}$ Department of Business, Faculty of Economics and Administration Sciences, Çanakkale Onsekiz Mart \\ University, Terzioğlu Kampüsü, Çanakkale, Turkey \\ ${ }^{2}$ Department of Econometrics, Faculty of Economics and Administration Sciences, Atatürk University, Erzurum, \\ Turkey \\ Correspondence: Ümran Şengül, Department of Business, Faculty of Economics and Administration Sciences, \\ Çanakkale Onsekiz Mart University, Terzioğlu Kampüsü, Çanakkale, Turkey. Tel: 90-286-218-0018-2896. \\ E-mail: umransengul@comu.edu.tr
}

Received: July 8, 2014 Accepted: August 6, 2014 Online Published: August 25, 2014

doi:10.5539/res.v6n3p81 URL: http://dx.doi.org/10.5539/res.v6n3p81

\begin{abstract}
Performance measurement is important in the comparison among enterprises. These comparisons provide the opportunity to compare strong and weak aspects of enterprises with each other that have same work structure producing similar products. Through the comparisons, enterprise aims to make its performance better by taking the best, good or average performing enterprises operating in its field as references to itself. In this study, information technology (IT) companies in Turkey are taken into consideration for effectiveness and performance measurement at the end of multiple time periods. To do this, we developed an alternative dynamic slack based model (DSBM) based on the slack based model (SBM) proposed by Tone (2001) and the dynamic data envelopment analysis (DEA) model proposed by Lotfi and Poursakhi (2012). The paper suggests that the alternative DSBM captures efficiency better than SBM.
\end{abstract}

Keywords: dynamic DEA, slack based model, dynamic slack based model, IT sector

\section{Introduction}

In order to reach its goals, each economic unit transforms the resources provided from its external environment to outcomes in terms of goods and services by using a specific production technology. Productivity can be defined as the relationship between the outcome produced by a production or service system and the income used in order to obtain this outcome, whereas performance can be defined as the level of success an enterprise showed in a specific time period (Kaya \& Ünal, 2010). Performance measurement is important in the comparison among enterprises. These comparisons provide the opportunity to compare strong and weak aspects of enterprises with each other that have same work structure producing similar products. Through the comparisons, enterprise aims to make its performance better by taking the best, good or average performing enterprises operating in its field as references to itself. In this study, information technology (IT) companies are taken into consideration for effectiveness and performance measurement.

Information technologies are the entire computer and communication technologies that collect, process, produce, store information, transfer it one place to another through the networks and put into service of users (Kılıç, 2005). Since the beginning of 1990s until today a rapid improvement has occurred in IT. This improvement resulted as productivity in production processes, contribution in competitive power and development in the economic field. Due to these reasons, industrial sectors based on information rapidly grow and their share in world trade constantly increases. This as well shows that information sector has a strategic importance. It is stated that in European Union countries, one fourth of GNP increase and $40 \%$ of productivity is related with information technologies (Turkey Republic Ministry Development [TRMP], 2007). In Turkey it is estimated that market share of information technologies is 3 billion US dollars. This market includes $68 \%$ hardware, $19 \%$ service and $13 \%$ software (TRMP, 2007). Now, information technologies have a place in development and GNP increase as important as energy (Kılıç, 2005). For this reason, in this study 16 information technology companies in Istanbul Stock Exchange (ISE) are taken into consideration for effectiveness and performance measurement at the end of multiple time periods. 
In production environments that include a wide range of incomes and outcomes, a nonparametric method, data envelopment analysis (DEA), is used to measure productivity. In the literature, the term DEA was first used by the CCR model in 1978 (Cooper et al., 2007). The CCR model aims to assign weights to incomes and outcomes, completing the production of the analyzed units through linear programming, and estimates a limit consisting of the units that show the best performance in the observation cluster. When the observed decision units do not produce on an optimal scale, which means, in the case of profits varying according to the scale, the CCR model falls behind in the technical effectiveness measurement because the model cannot measure scale effectiveness due to the model's structure. Banker, Charnes, and Cooper developed a model in 1984 (the BCC model) to measure technical effectiveness under the assumption that profit varies according to a scale, by separating technical effectiveness into its components, scale effectiveness and pure technical effectiveness. The model showed that technical effectiveness is equal to the multiplication of these two components (Cooper et al., 2007). Since 1978, many DEA models have been developed. One is the slack-based model (SBM). This model deals directly with the input excesses and the output shortfalls of Decision Making Units (DMUs). Furthermore, it is reference-set dependent; that is, the measure is determined only by its reference-set and is not affected by statistics over the entire data set. Tone (2001) demonstrated with at numerical example that the SBM is compatible with other measures and has potential applicability for practical purpose. However, the SBM measures the effectiveness of DMUs during a single period. To measure the change efficiency of DMUs at the end of multiple time periods dynamic DEA models have been proposed at different times (Sengupta, 1996; Tone \& Tsutsui, 2010; Tone, 2001). Dynamic DEA models are the relation between inputs and outputs in dynamic production. For example, A dynamic DEA model was developed by Lotfi and Poursakhi (2012).

In this study, taking Tone's (2001) SBM and Lotfi and Poursakhi's (2012) dynamic DEA model in to account, we developed an alternative dynamic slack-based model (DSBM). In practice, the data of 16 IT companies on the Istanbul Stock Exchange (ISE) in Turkey during the 2011-2012 period were used. Using input-output variables determined from the literature the DSBM effectiveness of the IT companies was measured. Company efficiency was measured fort he end of the period 2011-2012, with the static SBM separately for each year, and then the DSBM. The static and dynamic model results were compared.

The rest of this paper is organized as follows. In the second section, a literature review is discussed. In the third section, we develop a model for assessing dynamic SBM efficiency, input excesses, and the output shortfalls of IT in Turkey. In the fourth section, we explain the application of the model and discuss the result of the model. In the last section, we have interpreted our results and provide information about suggested further studies.

\section{Literature Review}

In the literature, many studies have used data envelopment analysis (DEA) and ISE data to measure company activities in various sectors. A literature summary including the DEA studies conducted between 2004 and 2012 for several business companies is shown in Table 1 .

Table 1. DEA studies in the literature made for various business companies

\begin{tabular}{|c|c|c|c|c|c|}
\hline 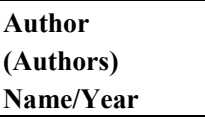 & $\begin{array}{l}\text { Business } \\
\text { Sector }\end{array}$ & $\begin{array}{l}\text { Number } \\
\text { of DMU }\end{array}$ & Input variables & Output variables & $\begin{array}{l}\text { DEA models } \\
\text { types }\end{array}$ \\
\hline $\begin{array}{l}\text { Y1lmaz and } \\
\text { Çıracı (2004) }\end{array}$ & Cement Sector & 15 & $\begin{array}{l}\text {-current ratio, -acid-test ratio -currency } \\
\text { rate } \\
\text {-net working capital/ total assets }\end{array}$ & $\begin{array}{l}\text {-return on sales } \\
\text {-return on equity } \\
\text { capital } \\
\text {-return on assets }\end{array}$ & $\begin{array}{l}\text { Output } \\
\text { oriented DEA }\end{array}$ \\
\hline $\begin{array}{l}\text { Yalama and } \\
\text { Sayım (2008) }\end{array}$ & $\begin{array}{l}\text { Manufacturing } \\
\text { sector }\end{array}$ & 157 & $\begin{array}{l}\text {-current ratio -financial leverage ratio - } \\
\text { equity capital/total assets-equity capital/ } \\
\text { total liability -short term liabilities/total } \\
\text { liabilities -real assets/equity capital-net } \\
\text { sales/ total assets -net sales/equity capital }\end{array}$ & $\begin{array}{l}\text { - return on equity } \\
\text { capital } \\
\text { - return on assets }\end{array}$ & $\begin{array}{l}\text { input oriented } \\
\text { CCR }\end{array}$ \\
\hline $\begin{array}{l}\text { Elitaş and Eleren } \\
\text { (2007) }\end{array}$ & Cement Industry & 10 & -liabilities -equity capital & $\begin{array}{l}\text { Net profitability } \\
\text { ratio }\end{array}$ & $\mathrm{CCR}, \mathrm{BCC}$ \\
\hline Y1ldız (2007) & $\begin{array}{l}\text { Manufacturing } \\
\text { sector }\end{array}$ & 105 & -firms' assets -capital & $\begin{array}{l}\text {-net sales } \\
\text {-net profit }\end{array}$ & $\begin{array}{l}\text { input oriented } \\
\text { CCR-BCC }\end{array}$ \\
\hline
\end{tabular}




\begin{tabular}{|c|c|c|c|c|c|}
\hline Kula et al. (2009) & Cement Sector & 16 & $\begin{array}{l}\text {-current ratio - financial leverage ratio } \\
\text { - equity capital/total assets,- short term } \\
\text { liabilities / total assets - real assets / equity } \\
\text { capital } \\
\text {-net sales/total assets -net sales/equity } \\
\text { capital }\end{array}$ & $\begin{array}{l}\text {-return on equity } \\
\text { capital } \\
\text {-return on assets } \\
\text {-return on sales }\end{array}$ & $\begin{array}{l}\text { input oriented } \\
\text { DEA }\end{array}$ \\
\hline $\begin{array}{l}\text { Ata and Yakut } \\
(2009)\end{array}$ & $\begin{array}{l}\text { Manufacturing } \\
\text { Sector }\end{array}$ & 15 & $\begin{array}{l}\text {-current ratio-total debt/equity capital, } \\
\text {-real assets/permanent capital } \\
\text {-accounts payable turnover }\end{array}$ & $\begin{array}{l}\text {-net profitability } \\
\text { ratio- asset } \\
\text { profitability rate } \\
\text { - accounts payable } \\
\text { turnover- stock } \\
\text { turnover } \\
\text { - stocks/liquid } \\
\text { assets, } \\
\text {-interest } \\
\text { expenses/net sales }\end{array}$ & CCR \\
\hline $\begin{array}{l}\text { Kaya and Ünal } \\
(2010)\end{array}$ & $\begin{array}{l}\text { Metal, Machinery } \\
\text { and Construction } \\
\text { Sector }\end{array}$ & 25 & $\begin{array}{l}\text {-current ratio-acid-test- financial leverage } \\
\text {-accounts receivable turnover-stock } \\
\text { turnover, } \\
\text {-real assets turnover-asset turnover }\end{array}$ & $\begin{array}{l}\text { - net profit /sales } \\
\text {-total assets/sales } \\
\text {-net profit/ equity } \\
\text { capital }\end{array}$ & $\begin{array}{l}\text { Output } \\
\text { oriented DEA }\end{array}$ \\
\hline Altın (2010) & Industry Sector & 142 & $\begin{array}{l}\text {-current ratio - liquidity rate,-cash rate - } \\
\text { financial leverage -financing rate }\end{array}$ & $\begin{array}{l}\text { - profitability ratio } \\
\text { of assets, } \\
\text { - market value }\end{array}$ & CCR \\
\hline $\begin{array}{l}\text { Tektüfekçi } \\
\text { (2010) }\end{array}$ & Technology Sector & 10 & $\begin{array}{l}\text {-current ratio, - accounts receivable } \\
\text { turnover, -total debt/equity capital }\end{array}$ & $\begin{array}{l}\text { - return on equity } \\
\text { capital } \\
\text { - earning per share } \\
\text { (loss) }\end{array}$ & DEA \\
\hline $\begin{array}{l}\text { Y. Türkmen and } \\
\text { Çağıl, (2011) }\end{array}$ & Energy Sector & 9 & -current ratio-equity capital/total assets & $\begin{array}{l}\text {-net profitability } \\
\text { ratio } \\
\text {-asset profitability } \\
\text { rate }\end{array}$ & DEA \\
\hline $\begin{array}{l}\text { Tehrani et al. } \\
(2012)\end{array}$ & $\begin{array}{l}\text { Private } \\
\text { Organization }\end{array}$ & 36 & $\begin{array}{l}\text {-liquidity, -activities,-leverage -economic } \\
\text { added value }\end{array}$ & -profitability ratio & $\begin{array}{l}\text { input-oriented } \\
\text { BCC }\end{array}$ \\
\hline $\begin{array}{l}\text { Halkos and } \\
\text { Tzeremes (2012) }\end{array}$ & $\begin{array}{l}\text { Manufacturing } \\
\text { Sector }\end{array}$ & 23 & $\begin{array}{l}\text {-total assets, -equity capital, } \\
\text {-administration- distribution- sales } \\
\text { expenses }\end{array}$ & $\begin{array}{l}\text { - net profitability } \\
\text { ratio- equity capital } \\
\text { profitability } \\
\text { - asset profitability }\end{array}$ & $\begin{array}{l}7 \text { diverse } \\
\text { DEA }\end{array}$ \\
\hline $\begin{array}{l}\text { Gerek et al. } \\
(2012)\end{array}$ & Cement Sector & 16 & $\begin{array}{l}\text {-Current ratio } \\
\text { - Total debt/equity capital } \\
\text { - real assets/permanent capital } \\
\text { - accounts payable turnover }\end{array}$ & $\begin{array}{l}\text { - stocks/ liquid } \\
\text { assets- accounts } \\
\text { receivable turnover } \\
\text { - stock turnover } \\
\text {-net profitability } \\
\text { ratio- interest } \\
\text { expenses/net sales }\end{array}$ & CCR \\
\hline
\end{tabular}

In the literature, apart from the above studies, these are some of the studies that related with SBM and the dynamic DEA. Emrouznejad (2003) provided an alternative DEA model based on several periods. This model is useful for DMUs with capital input. The dynamic efficiency results should reflect reality better than those based on static DEA models. Emrouznejad and Thanassoulis (2005) developed a method for assessing the performance of DMUs when their input-output levels are characterized by inter-temporal dependencies. The scholars suggested that dynamic models capture efficiency better than static models. Amirteimoori (2006) developed a new DEA with dynamic revenue efficiency. He showed that a convex combination of these period measures make up the efficiency of entire periods. Tone and Tsutsui (2010) developed a slack-based measure (SBM) framework called dynamic SBM. They classified carry-overs into four categories: desirable (good), undesirable (bad), free, and fixed. The authors developed dynamic SBM models that can evaluate the overall efficiency of decision-making units for entire terms as well as term efficiencies. Lotfi and Poursakhi (2012) developed a model for evaluating the relative efficiency of units that have time-dependent input-output. The model was 
presented in which the time-dependent effects of undesirable inputs and outputs were considered and time-dependent effects were formulated via time-dependent parameters.

\section{An Alternative Dynamic Slack-Based Model}

Radial and non-radial are two types of efficiency measurements. The CCR and BCC models present radial efficiency measurements. The slack-based measure of efficiency (SBM) is a non-radial measure of efficiency. The non-radial approach SBM deals with slack directly, but neglects the radial characteristics of inputs and/or outputs. Thus, the SBM measure reflects not only the weak efficiency values in CCR-efficiency but also the other (slack) inefficiencies (Cooper et al., 2007). The SBM deals directly with the input excesses and output shortfalls of the DMUs. However, the SBM measures the effectiveness of DMUs during a single period. It can be misleading to decide on the DMUs' performance during a single period. An optimization model should include the time change effect. For these cases, dynamic DEA models have been developed. In this study, based on Tone's (2001) SBM and Lotfi and Poursakhi's (2012) dynamic DEA model, we develop an alternative dynamic slack-based model (DSBM).

SBM by Tone (2001) is given below. In model, the production possibility set $P$ is defined as

$$
P=\{((x, y) \mid x \geq X \lambda, y \leq Y \lambda, \lambda \geq 0)\},
$$

where $\lambda$ is a nonnegative vector in $R^{n}$. In SBM is considered an expression for describing a certain DMUs $\left(x_{0}, y_{o}\right)$ as,

$$
\begin{aligned}
& x_{o}=X \lambda+s^{-}, \\
& y_{o}=Y \lambda-s^{+} .
\end{aligned}
$$

They are dealt with $n$ DMUs with the input and output matrices $X=\left(x_{i j}\right) \in \mathbb{R}^{m x n}$ and $Y=\left(y_{i j}\right) \in \mathbb{R}^{s x n}$, respectively. They are assumed that the data set is positive, i.e. $X>0$ and $Y>0$. The vectors $s^{-} \in \mathbb{R}^{m}$ and $s^{+} \in \mathbb{R}^{s}$ indicate the input excess and output shortfall of this expression, respectively, and are called slacks.

From the conditions $X>0$ and $\lambda \geq 0$, it holds $x_{o} \geq s^{-}$. SBM is as follows (Tone, 2001).

\section{[SBM]}

$$
\begin{gathered}
\text { minimize } \rho=\frac{1-(1 / m) \sum_{i=1}^{m} s_{i}^{-} / x_{i o}}{1-(1 / s) \sum_{r=1}^{s} s_{r}^{+} / y_{r o}} \\
\text { subject to } \quad x_{i o}=\sum_{j=1}^{n} x_{i j} \lambda_{j}+s_{i}^{-} \quad i=1, \ldots, m \\
y_{r o}=\sum_{j=1}^{n} y_{i j} \lambda_{j}-s_{r}^{+} \quad r=1, \ldots, s \\
\lambda_{j}, s_{i}^{-}, s_{r}^{+} \geq 0
\end{gathered}
$$

Here, it holds $0 \leq \rho \leq 1$.

Model 5 was developed by adding time dimension of Model 4. $\tau$, initial time period and $t=\tau, \ldots, \tau+T$ are get (Lotfi and Poursakhi 2012). Accordingly to we are developed DSBM model is given below;

\section{[Alternative DSBM]}

$$
\text { minimize } \beta=\frac{1}{T} \sum_{t=\tau}^{\tau+T}\left(\frac{1-(1 / m) \sum_{i=1}^{m} \frac{s_{i}^{t-}}{x_{i o}^{t}}}{1+(1 / s) \sum_{r=1}^{s} \frac{s_{r}^{t+}}{y_{r o}^{t}}}\right)
$$


subject to

$$
\begin{gathered}
x_{i o}^{t}=\sum_{j=1}^{n} x_{i j}^{t} \lambda_{j}+s_{i}^{t-}, \quad i=1, \ldots, m, t=\tau, \ldots, \tau+T \\
y_{r o}^{t}=\sum_{j=1}^{n} y_{i j}^{t} \lambda_{j}-s_{r}^{t+}, \quad r=1, \ldots, s, t=\tau, \ldots, \tau+T \\
\lambda_{j}, s_{i}^{t-}, s_{r}^{t+} \geq 0
\end{gathered}
$$

Here, it holds $0 \leq \beta \leq 1$. In an effort to estimate the efficiency of $\left(x_{o}, y_{o}\right)$, we formulate the alternative DSBM fractional program in $\lambda, s^{-}$and $s^{+}$. The effectiveness of DMUs are measured by taking values of input and output for a period in Model 4. While taking into consideration the input and output data in each period in Model 5 it is aimed to measure the effectiveness of DMUs at the end of a few period. According to the results in Model 5

A DMU $\left(x_{o}, y_{o}\right)$ is alternative DSBM-efficient if $\beta=1$. This condition is equivalent to $s_{i}^{t-}=0$ and $s_{r}^{t+}=0$, i.e., no input excesses and no output shortfalls in any optimal solution. For an inefficient DMU $\left(x_{o}, y_{o}\right)$, we have the expression:

$$
\begin{aligned}
& x_{i o}^{t}=\sum_{j=1}^{n} x_{i j}^{t} \lambda_{j}+s_{i}^{t-}, \\
& y_{r o}^{t}=\sum_{j=1}^{n} y_{i j}^{t} \lambda_{j}-s_{r}^{t+} .
\end{aligned}
$$

The DMU $\left(x_{o}, y_{o}\right)$ can be improved and become efficient by deleting the input excess and augmenting the output shortfall as follows:

$$
\begin{aligned}
& x_{o} \leftarrow x_{o}-s_{i}^{t-} \\
& y_{o} \leftarrow y_{o}+s_{i}^{t+}
\end{aligned}
$$

In some cases (such as financial ratios), negative outputs may be encountered. As in many DEA models, it is important to overcome of the negative outputs in evaluating the efficiency of SBMs. However, measuring the effectiveness in data sets containing negative data requires arrangements. Thus, a new scheme was introduced in the DEA-Solver-Pro 4.1 Manual, used by Düzakın and Düzakın (2007). The dynamic version of this scheme is as follows.

Let us suppose $y_{\text {ro }}^{t} \leq 0$. It is defined $\bar{y}_{r}^{t+}$ and $\underline{y}_{r}^{t+}$ by

$$
\begin{gathered}
\bar{y}_{r}^{t+}=\max _{j=1, \ldots, n}\left\{y_{r j}^{t} \mid y_{r j}^{t}>0\right\}, \\
\underline{y}_{r}^{t+}=\min _{j=1, \ldots, n}\left\{y_{r j}^{t} \mid y_{r j}^{t}>0\right\},
\end{gathered}
$$

If the output $r$ has no positive elements, then it is defined as $\bar{y}_{r}^{t+}=\underline{y}_{r}^{t+}=1$. The term is only replaced $s_{r}^{t+} / y_{r o}^{t}$ in the objective function in the following way. The value $y_{r o}^{t}$ is changed in the constrains.

$$
\begin{array}{cc}
\text { If } \bar{y}_{r}^{t+}>\underline{y}_{r}^{t+} \text {, the term is replaced by } & s_{r}^{t+} / \frac{\underline{y}_{r}^{t+}\left(\bar{y}_{r}^{t+}-\underline{y}_{r}^{t+}\right)}{\bar{y}_{r}^{t+}-y_{r o}^{t}} \\
\text { If } \bar{y}_{r}^{t+}=\underline{y}_{r}^{t+} \text { the term is replaced by } & s_{r}^{t+} / \frac{\left(\underline{y}_{r}^{t+}\right)^{2}}{B\left(\bar{y}_{r}^{t+}-y_{r o}^{t}\right)}
\end{array}
$$

where $\mathrm{B}$ is a large positive number, (in DEASolver $\mathrm{B}=100$ ). The score obtained is units invariant, i.e., it is independent of the units of measurement used.

\section{Application}


The income and outcome variables used to measure the effectiveness of the 16 IT companies with the alternative DSBM between 2011 and 2012, are as follows. The input variables are the Current Ratio, Acid-Test Ratio (Liquidity Ratio), Total Debt/Equity Capital, Short Term Debt/Total Assets, Long Term Debt/Total Assets, Equities/Total Assets, Total Debt/Total Assets. The output variables are the Net Profit Margin, Return on Equity, Total Return on Assets. Using model (4), the efficiency values at the end of 2011 and 2012 and the input excess and output shortfalls according to data from 2011 and 2012 were found (Table 2). Then using Model 5, the dynamic efficiency values at the end of the period 2011-2012 and input excess and output shortfalls separately for each year were found (Table 3). Model 5 is a nonlinear form. Without converting Model 5 to linear form it is solved with the General Algebraic Modeling System (GAMS) 23.1. GAMS is specifically designed for modeling linear, nonlinear and mixed integer optimization problems. The system is especially useful with large, complex problems.

Table 2. SBM effectiveness of 16 IT companies located ISE in Turkey in 2011-2012

\begin{tabular}{|c|c|c|c|c|c|c|c|c|c|c|c|c|c|c|c|c|c|c|c|c|c|c|c|c|c|}
\hline \multicolumn{13}{|c|}{2011 SBM Efficiency } & \multicolumn{13}{|c|}{2012 SBM Efficiency } \\
\hline DMU & $\rho$ & $s_{i}^{-}$ & $s_{2}^{-1}$ & $s_{3}^{-}$ & $s_{i}^{-}$ & $s_{5}^{-}$ & $s_{6}^{-}$ & $s_{7}^{-}$ & $s_{1}^{+}$ & $s_{2}^{+}$ & $s^{\dagger}$ & $\mathrm{RS}^{\top}$ & & $s_{1}^{-1}$ & $s_{2}^{n}$ & $s_{3}^{-}$ & 8 & $s_{\xi}^{2}$ & $s_{6}^{*}$ & 87 & $\frac{81}{8}$ & $i_{1}^{+}$ & $s_{2}^{+}$ & $s_{3}^{+}$ & $\mathrm{RS}^{\circ}$ \\
\hline $1 \#$ & 0.00 & 0.71 & 0.80 & 4.43 & 0.53 & 0.22 & 0.00 & 0.74 & 0.02 & 0.06 & 0.04 & $7 \#$ & 1.00 & 0.00 & 0.00 & 0.00 & 0.00 & 0.00 & 0.00 & 0.00 & 0.0 & 00 & 0.00 & 0.00 & $1 \#$ \\
\hline $2 \#$ & 0.00 & 0.22 & 0.33 & 6.49 & 0.35 & 0.47 & 0.00 & 0.81 & 0.01 & 0.04 & 0.03 & $7 \#$ & 0.08 & 0.95 & 0.77 & 1.63 & 0.15 & 0.43 & 0.24 & 0.57 & 0.0 & & 0.00 & 0.01 & $14 *$ \\
\hline $3 \#$ & 0.39 & 0.22 & 0.00 & 0.94 & 0.36 & 0.01 & 0.10 & 0.38 & 0.01 & 0.00 & 0.02 & $6=7 *$ & 1.00 & 0.00 & 0.00 & 0.00 & 0.00 & 0.00 & 0.00 & 0.00 & 0.0 & & 0.00 & 0.00 & $3 \#$ \\
\hline $4 \#$ & 1.00 & 0.00 & 0.00 & 0.00 & 0.00 & 0.00 & 0.00 & 0.00 & 0.00 & 0.00 & 0.00 & 4 & 1.00 & 0.00 & 0.00 & 0.00 & 0.00 & 0.00 & 0.00 & 0.00 & 0.0 & & 0.00 & 0.00 & 4 \\
\hline $5 \#$ & 1.00 & 0.00 & 0.00 & 0.00 & 0.00 & 0.00 & 0.00 & 0.00 & 0.00 & 0.00 & 0.00 & $5 \#$ & 1.00 & 0.00 & 0.00 & 0.00 & 0.00 & 0.00 & 0.00 & 0.00 & 0.0 & & 0.00 & 0.00 & $5 \#$ \\
\hline $6 \#$ & 1.00 & 0.00 & 0.00 & 0.00 & 0.00 & 0.00 & 0.00 & 0.00 & 0.00 & 0.00 & 0.00 & $6 \#$ & 0.26 & 0.00 & 0.07 & 1.67 & 0.52 & 0.00 & 0.04 & 0.52 & 0.0 & & 0.02 & 0.04 & $7 \#$ \\
\hline $7 \#$ & 1.00 & 0.00 & 5.33 & 0.00 & 0.00 & 0.00 & 0.00 & 0.00 & 0.00 & 0.00 & 0.00 & $7 \#$ & 1.00 & 0.00 & 0.00 & 0.00 & 0.00 & 0.00 & 0.00 & 0.00 & 0.0 & & 0.00 & 0.00 & $7 \#$ \\
\hline $8 \#$ & 0.00 & 5.04 & 0.00 & 0.04 & 0.05 & 0.00 & 0.60 & 0.05 & 0.02 & 0.08 & 0.06 & $7 \#$ & 0.25 & 5.17 & 5.47 & 0.00 & 0.02 & 0.00 & 0.58 & 0.02 & 0.0 & 0.01 & 0.03 & 0.03 & $7 \#$ \\
\hline $9 \#$ & 0.00 & 0.10 & 0.00 & 0.96 & 0.39 & 0.03 & 0.22 & 0.42 & 0.02 & 0.08 & 0.06 & $7 \#$ & 0.39 & 0.25 & 0.06 & 0.77 & 0.37 & 0.00 & 0.27 & 0.37 & & .02 & 0.00 & 0.01 & $7 \#, 14$ \\
\hline $10 \#$ & 0.69 & 0.06 & 0.00 & 1.09 & 0.17 & 0.01 & 0.00 & 0.18 & 0.00 & 0.00 & 0.01 & $4,6=7,7$ & 1.00 & 0.00 & 0.00 & 0.00 & 0.00 & 0.00 & 0.00 & 0.00 & & .00 & 0.00 & 0.00 & $10 \%$ \\
\hline $11 \#$ & 1.00 & 0.00 & 0.00 & 0.00 & 0.00 & 0.00 & 0.00 & 0.00 & 0.00 & 0.00 & 0.00 & $11 . \#$ & 0.32 & 0.66 & 0.00 & 0.45 & 0.19 & 0.03 & 0.10 & 0.21 & & .08 & 0.08 & 0.06 & 14 \\
\hline $12 \#$ & 1.00 & 0.00 & 0.00 & 0.00 & 0.00 & 0.00 & 0.00 & 0.00 & 0.00 & 0.00 & 0.00 & 127 & 0.05 & 0.37 & 1.02 & 0.01 & 0.00 & 0.00 & 0.10 & 0.00 & & .05 & 0.14 & 0.11 & $7 \#$ \\
\hline $13 \#$ & 1.00 & 0.00 & 0.00 & 0.00 & 0.00 & 0.00 & 0.00 & 0.00 & 0.00 & 0.00 & 0.00 & $13 \#$ & 1.00 & 0.00 & 0.00 & 0.00 & 0.00 & 0.00 & 0.00 & 0.00 & & .00 & 0.00 & 0.00 & $13 \#$ \\
\hline $14 \#$ & 1.00 & 0.00 & 0.00 & 0.00 & 0.00 & 0.00 & 0.00 & 0.00 & 0.00 & 0.00 & 0.00 & $1.4 \%$ & 1.00 & 0.00 & 0.00 & 0.00 & 0.00 & 0.00 & 0.00 & 0.00 & 0.0 & .00 & 0.00 & 0.00 & 14 \\
\hline $15 \#$ & 0.41 & 0.00 & 0.00 & 0.35 & 0.18 & 0.02 & 0.23 & 0.20 & 0.00 & 0.04 & 0.03 & $7 \#, 12 \#$, & 0.17 & 1.47 & 1.33 & 0.88 & 0.40 & 0.02 & 0.35 & 0.4 & 0.0 & .02 & 0.00 & 0.01 & $14 \#$ \\
\hline $16 \#$ & 0.33 & 6.35 & 3.01 & 0.05 & 0.00 & 0.04 & 0.47 & 0.05 & 0.07 & 0.01 & 0.00 & $12 \%$ & 1.00 & 0.00 & 0.00 & 0.00 & 0.00 & 0.00 & 0.00 & 0.00 & & .00 & 0.00 & 0.00 & $16 \#$ \\
\hline
\end{tabular}

*Reference set

Table 3. The Alternative DSBM effectiveness of 16 IT companies located ISE in Turkey in 2011-2012

\begin{tabular}{|c|c|c|c|c|c|c|c|c|c|c|c|c|c|c|c|c|c|c|c|c|c|c|}
\hline \multicolumn{23}{|c|}{ 2011-2012 Alternative DSBM Efficiency } \\
\hline $\mathrm{DMU}$ & 0 & $s_{1}^{1-}$ & $s_{2}^{1-}$ & $s_{3}^{1-}$ & $s_{4}^{1-}$ & $s_{5}^{1-}$ & $s_{6}^{1-}$ & $s_{7}^{1-}$ & $s_{1}^{2-}$ & $s_{2}^{2-}$ & $s_{3}^{2-}$ & $s_{4}^{2-}$ & $s_{5}^{2-}$ & $s_{6}^{2-}$ & $s_{7}^{2-}$ & $s_{1}^{1+}$ & $s_{2}^{1+}$ & $s_{3}^{1+}$ & $s_{1}^{2+}$ & $s_{2}^{2+}$ & $s_{3}^{3+}$ & RS' \\
\hline $1 \#$ & 1.00 & 0.00 & 0.00 & 0.00 & $\overline{0.00}$ & 0.00 & 0.00 & 0.00 & 0.00 & 0.00 & 0.00 & 0.00 & 0.00 & 0.00 & 0.00 & 0.00 & 0.00 & 0.00 & 0.00 & 0.00 & 0.00 & $1 \#$ \\
\hline $2 \#$ & 0.04 & 0.4 & 0.39 & 6.48 & 0.37 & 0.4 & 0.00 & 0.81 & 0.93 & 0.74 & 1.63 & 0.15 & 0.42 & 0.24 & 0.57 & 0.02 & 0.02 & 0.01 & 0.03 & 0.00 & 0.01 & $14 *$ \\
\hline $3 \#$ & 1.00 & 0.00 & 0.00 & 0.00 & 0.00 & 0.00 & 0.00 & 0.00 & 0.00 & 0.00 & 0.00 & 0.00 & 0.00 & 0.00 & 0.00 & 0.00 & 0.00 & 0.00 & 0.00 & 0.00 & 0.00 & $3 \#$ \\
\hline $4 \#$ & 1.00 & 0.00 & 0.00 & 0.00 & 0.00 & 0.00 & 0.00 & 0.00 & 0.00 & 0.00 & 0.00 & 0.00 & 0.00 & 0.00 & 0.00 & 0.00 & 0.00 & 0.00 & 0.00 & 0.00 & 0.00 & 4 \\
\hline $5 \#$ & 1,00 & 0.00 & 0.00 & 0.00 & 0.00 & 0.00 & 0.00 & 0.00 & 0.00 & 0.00 & 0.00 & 0.00 & 0.00 & 0.00 & 0.00 & 0.00 & 0.00 & 0.00 & 0.00 & 0.00 & 0.00 & $5 \#$ \\
\hline $6 \#$ & 1.00 & 0.00 & 0.00 & 0.00 & 0.00 & 0.00 & 0.00 & 0.00 & 0.00 & 0.00 & 0.00 & 0.00 & 0.00 & 0.00 & 0.00 & 0.00 & 0.00 & 0.00 & 0.00 & 0.00 & 0.00 & $6 \#$ \\
\hline $7 \#$ & 1.00 & 0.00 & 0.00 & 0.00 & 0.00 & 0.00 & 0.00 & 0.00 & 0.00 & 0.00 & 0.00 & 0.00 & 0.00 & 0.00 & 0.00 & 0.00 & 0.00 & 0.00 & 0.00 & 0.00 & 0.00 & $7 \#$ \\
\hline $8 \#$ & 0.12 & 5.38 & 5.58 & 0.08 & 0.08 & 0.00 & 0.68 & 0.08 & 5.69 & 5.88 & 0.06 & 0.07 & 0.00 & 0.69 & 0.07 & 0.02 & 0.06 & 0.04 & 0.01 & 0.00 & 0.01 & $7 \#$ \\
\hline $9 \#$ & 0.19 & 0.27 & 0.06 & 0.96 & 0.40 & 0.01 & 0.22 & 0.42 & 0.25 & 0.06 & 0.77 & 0.37 & 0.00 & 0.27 & 0.37 & 0.03 & 0.07 & 0.05 & 0.02 & 0.00 & 0.01 & $7 \#, 14$ \\
\hline $10 \#$ & 1,00 & 0.00 & 0.00 & 0.00 & 0.00 & 0.00 & 0.00 & 0.00 & 0.00 & 0.00 & 0.00 & 0.00 & 0.00 & 0.00 & 0.00 & 0.00 & 0.00 & 0.00 & 0.00 & 0.00 & 0.00 & $10 \#$ \\
\hline $11 \#$ & 1.00 & 0.00 & 0.00 & 0.00 & 0.00 & 0.00 & 0.00 & 0.00 & 0.00 & 0.00 & 0.00 & 0.00 & 0.00 & 0.00 & 0.00 & 0.01 & 0.00 & 0.00 & 0.00 & 0.00 & 0.00 & $11 \%$ \\
\hline $12 \#$ & 1.00 & 0.00 & 0.00 & 0.00 & 0.00 & 0.00 & 0.00 & 0.00 & 0.00 & 0.00 & 0.00 & 0.00 & 0.00 & 0.00 & 0.00 & 0.00 & 0.00 & 0.00 & 0.00 & 0.00 & 0.00 & $1.2 \#$ \\
\hline $13 \#$ & 1,00 & 0.00 & 0.00 & 0.00 & 0.00 & 0.00 & 0.00 & 0.00 & 0.00 & 0.00 & 0.00 & 0.00 & 0.00 & 0.00 & 0.00 & 0.00 & 0.00 & 0.00 & 0.00 & 0.00 & 0.00 & $13 \#$ \\
\hline $14 \#$ & 1.00 & 0.00 & 0.00 & 0.00 & 0.00 & 0.00 & 0.00 & 0.00 & 0.00 & 0.00 & 0.00 & 0.00 & 0.00 & 0.00 & 0.00 & 0.00 & 0.00 & 0.00 & 0.00 & 0.00 & 0.00 & 1.4 \\
\hline $15 \#$ & 0.31 & 0.00 & 0.04 & 0.31 & 0.16 & 0.01 & 0.18 & 0.18 & 0.17 & 0.27 & 0.71 & 0.29 & 0.01 & 0.06 & 0.30 & 0.00 & 0.05 & 0.04 & 0.07 & 0.09 & 0.07 & $7 \#, 14$ \\
\hline $16 \#$ & 1.00 & 0.00 & 0.00 & 0.00 & 0.00 & 0.00 & 0.00 & 0.00 & 0.00 & 0.00 & 0.00 & 0.00 & 0.00 & 0.00 & 0.00 & 0.00 & 0.00 & 0.00 & 0.00 & 0.00 & 0.00 & $16 \#$ \\
\hline
\end{tabular}

*Reference set 
The variables at Table 2 are defined as follows;

$s_{1}^{-}$: Current ratio's excess

$s_{2}^{-}$: Acid-Test Ratio's excess

$s_{3}^{-}$: Total Debt/Equity Capital's excess

$s_{4}^{-}$: Short Term Debt/Total Assets's excess

$s_{5}^{-}$: Long Term Debt/Total Assets's excess

$s_{6}^{-}$: Equities/Total Assets's excess

$s_{7}^{-}$: Total Debt/Total Assets's excess

$s_{1}^{+}$: Net Profit Margin's shortfall

$s_{2}^{+}$: Return on Equity's shortfall

$s_{3}^{+}$: Total Return on Assets's shortfall

According to the results, 8 out of 16 companies and 9 out of 16 companies are efficient at the and of 2011 and 2012 respectively. According to the results of the least efficient company 1\# in 2011 (Table 2), this company should decrease 0,71 unit for its Ratio's Value; 0,80 unit for its Acid-Test Ratio's value; 4,43 unit for its Total Debt/Equity capital's value; 0,53 unit for its short term Debt/Total Assets's value; 0,22 unit for its Long Term Debt/Total Assets's value and lastly 0,74 unit for its Total Debt/ Total Assets's value. On the other hand, this company should increase its outcomes, 0,02 unit for its Net Profit Margin; 0,06 unit for its Return on Equity and for its Total Return on Assets. Sinilarly, it is commented on the other ineffective companies. For 2011, our general assessment is that to be effective from a financial perspective, Turkey; IT companies should decrease the amount of inputs in order of importance as follows: Total Debt/Equity Capital, Current Ratio, Acid-Test Ratio, Total Debt/Total Assets, Short Term Debt/Total assets, Equities/Total Assets, Long Term Debt/Total Assets. According to this ranking in 2011, excessive Total Dept/Equity Capital represents a major challenge to a company's effectiveness. In terms of output variables, following outputs, in order of importance, should be increased: Return on Equity, Return on Total Assets, Net Profit Margin. According to these results, to increase effectiveness, a company should focus on increasing the return on equity of their outputs. In 2012, this importance ranking varied. According to the results for 2012, the input variables should be reduced in the following order: Current Ratio's excess, Acid-Test Ratio's excess, Total Debt/Equity Capital's excess, Total Debt/Total Assets's excess, Equities/Total Assets's excess, Short Term Debt/Total Assets's excess, Long Term Debt/Total Assets's excess. That is, according to the period, the ranking of the variables that determine effectiveness has changed. Therefore, examining a single period to measure firms' effectiveness can be misleading. Companies that are inefficient in 2011 and efficient in 2012 (companies \#1, \#3, \#10, \#16) as is shown in Table 2. If you want to make a comment for whole period by taking the arithmetic average of 2011-2012 effectiveness for these companies it will be said that these companies are not effective. But these companies are considered by the alternative DSBM model as efficient for the entire period 2011-2012. Similar comment can be made for \#6, \#11, \#12 companies too. Namely companies that are efficient in 2011 and inefficient in 2012 (companies \#6, \#11, \#12) are considered by the alternative DSBM model as efficient for the entire period 2011-2012.

In this study, we developed an alternative DSBM and analyzed company effectiveness in 2011-2012. Table 3 shows the results of the alternative DSBM. The variable definitions in Table 3 are the same as in Table 2, but the superscript represents 1: in 2011 and 2: in 2012. According to the results, 12 out of 16 companies were efficient the end of the 2011-2012 period. According to Table 3, to be effective in 2011, the first input variables Total Debt/Equity Capital should be decreased, and the required output variable Return on Equity should be increased. In addition, in 2012, to be effective the first input variable the Current Ratio should be decreased and the required output variable Net Profit Margin's should be increased. These ranking is defined according to the results in Table 2. For example for Current Ratio's excess $\left(s_{1}^{-}\right)$variable all companies values in Table 2 were collected. The found values are listed from biggest to smallest. Similarly, the same procedure was performed for other variables. Thus the order of importance of variables is determined. Order of importance of these variables is determined as in alternative DSBM like that. Determined this ranking is relative. Ranking results may vary if the dealt sector and variables's numbers and qualification change. 
According to these results, the importance of the company during a specific period changed, according to the input-output variables. The results for the effectiveness of the SBM and the alternative SBM are given in Table 4. According to this ranking, the number of effectiveness companies is increased. Because the model is dynamic.

Table 4. SBM and Alternative SBM effectiveness results

\begin{tabular}{lcccc}
\hline DMU & $\mathbf{2 0 1 1}$ & $\mathbf{2 0 1 2}$ & Average efficiency from Tone (2001) & Alternative DSBM \\
\hline $1 \#$ & 0 & 1 & 0,5 & 1 \\
$2 \#$ & 0 & 0,08 & 0,04 & 0,04 \\
$3 \#$ & 0,39 & 1 & 0,69 & 1 \\
$4 \#$ & 1 & 1 & 1 & 1 \\
$5 \#$ & 1 & 1 & 1 & 1 \\
$6 \#$ & 1 & 0,26 & 0,63 & 1 \\
$7 \#$ & 1 & 1 & 1 & 1 \\
$8 \#$ & 0 & 0,25 & 0,13 & 0,12 \\
$9 \#$ & 0 & 0,39 & 0,20 & 0,19 \\
$10 \#$ & 0,69 & 1 & 0,85 & 1 \\
$11 \#$ & 1 & 0,32 & 0,66 & 1 \\
$12 \#$ & 1 & 0,05 & 0,53 & 1 \\
$13 \#$ & 1 & 1 & 1 & 1 \\
$14 \#$ & 1 & 1 & 1 & 1 \\
$15 \#$ & 0,41 & 0,17 & 0,29 & 0,31 \\
$16 \#$ & 0,33 & 1 & 0,67 & 1 \\
\hline
\end{tabular}

2011 and 2012 columns in Table 4 were found by using Model 4. Each period is evaluated within itself with Model 4. The alternative DSBM model that we have developed with company effectiveness are found by taking into consideration all periods. When periods taken independently one from another, in order to measure the arithmetic effectivenesss at the end of the period the arithmetic average of the efficiency values that measured each period can be taken. (Emrouznejad, 2003; Tone \& Tsutsui, 2010). When the average of 2011 and 2012 SBM effectiveness are taken the values in Column 4 of Table 4 are obtained. However, this efficiency values can not reflect fully the efficiency values which are at the end of theperiod. Company effectiveness at the end of the 2011-2012 period with the alternative DSBM is solved by using Model 5. Results are given in Column 5 of Table 4. According to this ranking, the number of effectiveness companies is increased. More realistic results are obtained that values of variables are taken into account considering two periods not a single period. Because determination of company effectiveness by looking at one period may produce misleading results. From this perspective when measuring company effectiveness more realistic results can be obtained by calculations that made considering not only in single time but also a few time period. In addition, in order to make inefficient firms effective the receivable reference firms are given (reference set) in Table 3 and Table 4. In both models, the most indicated referenced firms are 7 \# and 14 \# respectively. According to these results with reference to these companies preventing the companies to take measures to eliminate inefficiencies for 2012 and forthcoming years.

\section{Conclusion and Future Research}

The purpose of this paper was to develop an alternative dynamic SBM (alternative DSBM). The alternative DSBM measures the efficiency of entire periods. The model provides input excess and output shortfalls for the DMUs in each period. The model closely follows the SBM introduced by Tone (2001) and the dynamic DEA developed by Lotfi and Poursakhi (2012) for assessing the dynamic slack efficiency performance of DMUs. The alternative DSBM can evaluate a non-radial measure of the efficiency of DMUs entire terms. In a real-life application, the methodology measured the effectiveness of 16 IT companies on the Turkey ISE in the 
2011-2012 period. We obtained the dynamic efficiencies of each company in two periods along with the efficiency of the entire period and we compared the results of the dynamic and static models (Section 4). According to the results, a company which is effective in a period may not be effective for the next period in SBM model. Because the effectiveness measurement are made according to the data considered only the period that is taken into consideration. However in the alternative DSBM periods are discussed as a whole but not individually. Thus, exchange of datas in the period is reflected to the effectiveness results. Indeed Model 5 results demonstrate this (Table 4). Also with improved the alternative DSBM model both effectiveness of companies can be measured and knowledge related with reformation in input-output variable values can be obtained. The discussion on this topic was made in section 4 . According to the results ineffective $(2 \#, 8 \#, 9$, 15 \#) firms in 2011, the first input variables Total Debt/Equity Capital should be decreased, and the required output variable Return on Equity should be increased. In addition, in 2012, to be effective the first input variable the Current Ratio should be decreased and the required output variable Net Profit Margin's should be increased. Further research can improve the model. In future studies, in addition to the financial criteria, by giving a place to non-financial criteria (company's reputation, customer satisfaction, employee loyalty, public opinion, brand value etc.), quantitative and qualitative factors can be included in the problem. Since these criteria involve subjective judgments fuzzy dynamic DEA methods can be used.

\section{References}

Altın, H. (2010). Financial efficiency test of the ISE industrial companies in the global crisis environment: Data envelopment analysis Application. Anadolu University Journal of Social Sciences, 10(2), 15-30. http://www.anadolu.edu.tr/arastirma/hakemli_dergiler/sosyal_bilimler/pdf/2010-2/2010_02_02.pdf

Amirteimoori, A. (2006). Data envelopment analysis in dynamic framework. Applied Mathematics and Computation, 181(1), 21-28. Retrieved May 28, 2014. http://dx.doi.org/ 10.1016/j.amc.2006.01.003

Ata, A. H., \& Yakut. E. (2009). Measurement of financial performance-based activity: Manufacturing sector application. Journal of Social Sciences Institute, 18(2), 80-100. http://kosbed.kocaeli.edu.tr/sayi18 /ata-yakut.pdf

Banker, R. D., Charnes, A., \& Cooper, W. W. (1984). Some models for estimating technical and scale inefficiencies in data envelopment analysis. Management Sciences, 30(9), 1078-1092. http://dx.doi.org $/ 10.1287$ /mnsc.30.9.1078

Cooper, W. W., Seiford, L. M., \& Tone, K. (2007). Data Envelopment Analysis A Comprehensive Text with Models, Applications, Rferences and DEA-Solver Software (2nd ed.). Springer.

Düzakın, E., \& Düzakın, H. (2007). Measuring the Performance of Manufacturing Firms with Super Slacks Based Model of Data Envelopment Analysis: An Application of 500 Major Industrial Enterprises in Turkey. European Journal of Operational Research, 182(3), 1412-1432. http://dx.doi.org/10.1016 j.ejor.2006.09.036

Elitaş, C., \& Eleren, A. (2007). Efficiency registered business in cement sector efficiency analysis with DEA method. Journal of Economic Perspetive in Gazi University, 18(64), 103-122. http://ekonomikyaklasim.org /pdfs2/EYD_V18_N64_A06.pdf

Emrouznejad, A., (2003). An Alternative DEA Measure: A Case of OECD Countries. Applied Economics Letters, 10(12), 779-782. http://dx.doi.org/10.1080/1350485032000126703

Emrouznejad, A., \& Emmanuel T. (2005). A Mathematical Model for Dynamic Efficiency Using Data Envelopment Analysis. Applied Mathematics and Computation, 160(2), 363-378. http://dx.doi.org /10.1016/j.amc.2003.09.026

Gerek, I. H., Erdiş, E., \& Yakut, E. (2012). Financial Performance Based Efficiency Measurement: Application of Cement Industry. e-journal of New World Sciences Academy, 7(1), 311-321. $\mathrm{http}: / /$ www.newwsa.com/makale_detay.asp?d=2\&makale_detay_id=2704\&dergi_id=1\&sayi_id=247

Halkos, G. E., \& Tzeremes, N. G. (2012). Industry performance evaluation with the use of financial ratios: An application od bootstrapped DEA. Expert Systems with Applications, 39(5), 5872-5880. http://dx.doi.org/10.1016/j.eswa.2011.11.080

Kaya, A., \& Ünal, G. (2010). The Effects of the Global Financial Crisis Businesses Efficiency and Performance: The Case of the 2008 Financial Crisis. Istanbul University, Faculty of Economics, Journal of Econometrics and Statistics, 11, 61-89. http://www.journals.istanbul.edu.tr/iuekois/article/view/1023005405 
Kılıç, S., (2005). IT Industry Electronic Document Management Approach (Unpublished master's thesis). Marmara University Institute of Turkish Studies, Information and Records Management Department, İstanbul, Turkey.

Kula,V., Kandemir, T., \& Özdemir, L. (2009). DEA Malmquist Total Factor Productivity Measurement: A Study of Cement Companies listed on the ISE. Journal of Economic Research, 9(17), 187-202. Retrieved fromhttp://sead.selcuk.edu.tr/sead/article/download/217/213

Lotfi, F. H., \& Poursakhi, N. (2012). A Mathematical Model for Dynamic Efficiency Using Desirable and Undesirable Input-Output. Applied Mathematical Sciences, 6(3), 141-151. Retrieved from http:/www.m-hikari.com/ams /ams-2012/ams-1-4-2012/lotfiAMS1-4-2012-2.pdf

Sengupta, J. K. (1996). Systematic measures of dynamic Farrell efficiency. Applied Economics Letters, 3(2), 91-94. http://dx.doi.org/10.1080/135048596356771

Tehrani, R., Mehragan, M. R., \& Golkani, M. R. (2012). A Model for Evaluating Financial Performance of Companies by Data Envelopment Analysis - A Case Study of 36 Corporations Affiliated with a Private Organization. International Business Research, 5(8), 8-16. http://dx.doi.org/10.5539/ibr.v5n8p8

Tektüfekçi, F. (2010). Evaluation of financial efficiency by Data Envelopment Analysis (DEA) in İstanbul Stock Exchange (ISE) listed publicly traded technology companies. Journal of Organization and Management Science Journal, 2(2), 69-77. Retrieved from http://www.sosbilko.net/dergi_YBD/arsiv/2010_2/08fatma _tektufekci.pdf

Turkey Republic Ministry Development (TRMP). Development Plan, 2007-2013. Retrieved from http://www.mod.gov.tr/en/SitePages/mod_plan.aspx

Tone, K., (2001). A Slacks-Based Measure of Effciency in Data Envelopment Analysis. European Journal of Operational Research, 130, 498-509. Retrieved from http://wenku.baidu.com/view /84e4d6687e21af45b307a8a1

Tone, K., \& Tsutsui, M., 2010. Dynamic DEA: A Slacks-Based Measure Approach. Omega, 38(3-4), $145-156$. http://dx.doi.org/10.1016/j.omega.2009.07.003

Y.Türkmen, S., \& Çağıl, G. (2011). Evaluation with DEA to financial activities in the energy companies listed on the ISE. $15^{\text {th }}$ National Finance Symposium. Malatya,Turkey.

Yalama, A., \& Sayım, M. (2008). Evaluation of manufacturing sector performance with Data Envelopment Analysis. Journal of Dokuz Eylul University of Economic and Administrative Sciences, 23(1), 89-107. Retrieved from http://iibf.deu.edu.tr/deuj/index.php/cilt1-sayi1/article/view/233/pdf_214

Yıldız, A. (2007). Evaluation of efficiency for manufacturing firms. Gazi University, Journal of Economics and Administrative Sciences, 9(2), 91-103. http://dergi.iibf.gazi.edu.tr/dergi_v1/9/2/6.pdf

Yılmaz, M. K., \& Çıracı, D. (2004). Cement companies traded on the ISE, in terms of liquidity and profitability efficiency by using Data Envelopment Analysis. World Journal of Science in Accounting, 6(3), 129-148. Retrieved from http://www.mkyilmaz.net/makaleler/makale16.pdf

\section{Copyrights}

Copyright for this article is retained by the author(s), with first publication rights granted to the journal.

This is an open-access article distributed under the terms and conditions of the Creative Commons Attribution license (http://creativecommons.org/licenses/by/3.0/). 